Supporting Information

\title{
Ionic Liquid-Modified Microporous ZnCoNC-Based Electrocatalysts for Polymer Electrolyte Fuel Cells
}

Min Wang, ${ }^{\dagger, \downarrow}$ Huixin Zhang, ${ }^{\ddagger}$ Gnanavel Thirunavukkarasu, ${ }^{\S}$ Ihtasham Salam,,$\|$ John R. Varcoe, ${ }^{\|}$Peter Mardle, ${ }^{\ddagger}$ Xiaoying Li,${ }^{\S}$ Shichun $\mathrm{Mu},{ }^{\dagger}$ Shangfeng $\mathrm{Du}^{*}, \$$

†State Key Laboratory of Advanced Technology for Materials Synthesis and Processing, Wuhan University of Technology, Wuhan 430070, China

${ }^{\ddagger}$ School of Chemical Engineering, University of Birmingham, Birmingham B15 2TT, U.K.

${ }^{\S}$ School of Metallurgy and Materials, University of Birmingham, Birmingham B15 2TT, U.K.

"Department of Chemistry, University of Surrey, Guildford GU2 7XH, U.K.

*E-mail: $\underline{\text { s.du@bham.ac.uk }}$

\section{Experimental}

\section{Chemicals and materials}

$\mathrm{Co}\left(\mathrm{NO}_{3}\right)_{2} .6 \mathrm{H}_{2} \mathrm{O}, \quad \mathrm{Zn}\left(\mathrm{NO}_{3}\right)_{2} \cdot 6 \mathrm{H}_{2} \mathrm{O}, \quad$ 2-methylimidazole, 1-butyl-3-methylimidazolium bis(trifluoromethylsulfonyl)imide ([BMIM][NTf2]), and $\mathrm{KOH}$ were purchased from SigmaAldrich (UK). Methanol, ethanol, isopropanol (IPA) and $\mathrm{HClO}_{4}$ were obtained from Fisher Scientific (UK). Pt/C catalyst ( $20 \mathrm{wt} \%$, FuelCellStore, USA) is used as the benchmark catalyst in half cell measurement. Commercial gas diffusion electrodes (GDEs) with a Pt loading of 0.4 $\mathrm{mg}_{\mathrm{Pt}} \mathrm{cm}^{-2}$ and PtRu/C catalyst (HISPEC 12100, $50 \mathrm{wt} \% \mathrm{Pt}, 25 \mathrm{wt} \% \mathrm{Ru}$ ) used for AEMFC testing were obtained from Johnson Matthey Fuel Cell Ltd. (UK). Nafion dispersion (D1021, $10 \mathrm{wt} \%$ in water) and Nafion ${ }^{\circledR} 212$ membranes were obtained from Ion Power Inc (USA). Sigrace 39 BC and TGP-H-060 (1\% PTFE wet proofed, FuelCellStore (USA), product 590105)) carbon paper were used as the gas diffusion layers (GDLs) in PEMFCs and AEMFCs, respectively. Ultrapure water (UPW, $18.2 \mathrm{M} \Omega \mathrm{cm}$ ) from a Millipore water system was used in all experiments. All materials and chemicals were used as received without any further purification.

\section{Synthesis of $\mathrm{ZnCoNC}$}

The ZIF-ZnCo precursor was prepared using a modification of a previously reported method. ${ }^{1}$ In a typical synthesis, $2.184 \mathrm{~g} \mathrm{Co}\left(\mathrm{NO}_{3}\right)_{2} \cdot 6 \mathrm{H}_{2} \mathrm{O}, 4.464 \mathrm{~g}$ and $\mathrm{Zn}\left(\mathrm{NO}_{3}\right)_{2} \cdot 6 \mathrm{H}_{2} \mathrm{O}$ were dissolved in $60 \mathrm{~mL}$ methanol to form a clear pink solution, which was subsequently added to a solution of 
$4.926 \mathrm{~g}$ 2-methylimidazole in $60 \mathrm{~mL}$ of methanol. The mixed solution was stirred under ambient conditions for $36 \mathrm{~h}$, where a precipitate formed that was subsequently collected by centrifugation and rinsed with ethanol (until the supernatant was colorless). After drying at $60^{\circ} \mathrm{C}$ for $12 \mathrm{~h}$, purple powder was collected (denoted as ZIF-ZnCo). Finally, about $180 \mathrm{mg}$ $\mathrm{ZnCoNC}$ catalysts were obtained by sintering the ZIF-ZnCo powder to $900^{\circ} \mathrm{C}$ in a quartz tube furnace under $\mathrm{N}_{2}$ at a heating rate of $5^{\circ} \mathrm{C} \mathrm{min}^{-1}$ and keeping at this temperature for $2 \mathrm{~h}$.

\section{Preparation of IL-modified ZnCoNC catalysts}

[BMIM] $\left[\mathrm{NTf}_{2}\right]$ was diluted with IPA to make solutions with concentrations of $10,1,0.1$, and $0.01 \mathrm{mg} \mathrm{mL}^{-1}$. The IL solutions were added to controlled amounts of $\mathrm{ZnCoNC}$ catalyst to obtain IL-modified catalysts containing IL/ZnCoNC contents of $200 \mathrm{wt} \%, 20 \mathrm{wt} \%, 2 \mathrm{wt} \%$, and 0.2 $\mathrm{wt} \%$, respectively. A control sample was prepared by adding IPA only to $\mathrm{ZnCoNC}$. The mixed slurries were put into an ultrasonic bath for $30 \mathrm{~min}$, to ensure the uniform dispersion of the $\mathrm{ZnCoNC}$, and subsequently dried in a vacuum desiccator at room temperature until the solvent was completely evaporated. The IL-modified $\mathrm{ZnCoNC}$ catalysts obtained are designated ZnCoNC-IL200, ZnCoNC-IL20, ZnCoNC-IL2, ZnCoNC-IL0.2, and ZnCoNC-IL0 (based on the $w t \%$ of IL).

\section{Physicochemical characterization}

The morphology and structural features of the catalysts were characterized using a scanning electron microscope (SEM, JSM 7100F) and a high-resolution transmission electron microscope (HRTEM, Talos F200X) operating at an acceleration voltage of $200 \mathrm{kV}$. Elemental mapping with HRTEM was carried out using the associated super-X EDS system with four silicon drift detectors (SDDs) (Bruker). Powder X-ray diffraction (XRD) patterns, recorded on an X-ray diffractometer (D2 PHASER) with monochromatic Co-K $\alpha$ radiation source, were used to characterize the crystal phases of the catalysts. X-ray photoelectron spectroscopy (XPS) measurements were carried out on a Thermo Fisher Scientific NEXSA spectrometer. The samples were analysed using a micro-focused monochromatic Al-K $\alpha$ source $(72 \mathrm{~W})$ over an area of approximately $400 \mu \mathrm{m}$ in diameter. Charge neutralisation of the sample was achieved using a combination of both low energy electrons and argon ions. The ex situ specific surface areas (SSA) of catalysts were analysed through the Brunauer-Emmett-Teller (BET) method at low temperature (77 K) by using a BET analyser (Belsorp-Max, Japan).

\section{Half-cell rotating disk electrode (RDE) measurement}

Half-cell RDE measurements were used to evaluate the ex situ catalyst activities using a standard 3-electrode cell connected with an Autolab PGSTAT302N potentiostat (Metrohm Ltd., UK). Typically, a homogeneous $10 \mathrm{mg}_{\mathrm{ZnCoNC}} \mathrm{mL}^{-1}$ catalyst ink was prepared by adding the catalysts to a mixture of UPW, IPA, and Nafion D1021 dispersion at a fixed volume ratio of 7:3:0.5, and ultrasonicating for $10 \mathrm{~min}$. For RDE measurements, a Pt wire counter electrode $(\mathrm{CE})$ and an $\mathrm{Ag} / \mathrm{AgCl}$ (internal solution = saturated aqueous $\mathrm{KCl}$ ) reference electrode $(\mathrm{RE})$ were used. The mirror-polished glassy carbon electrode (GCE, $0.196 \mathrm{~cm}^{2}$ ) RDE were coated with catalyst at $0.1 \mathrm{mg}_{\mathrm{ZnCoNC}} \mathrm{cm}^{-2}$ to form thin-film working electrodes (WE). Aqueous $0.1 \mathrm{M}$ $\mathrm{HClO}_{4}(\mathrm{aq})$ and $0.1 \mathrm{M} \mathrm{KOH}(\mathrm{aq})$ were used as the electrolytes for the acidic and alkaline tests, 
respectively, and were maintained at $25^{\circ} \mathrm{C}$ using a thermostatic water bath.

After the electrolyte was saturated with $\mathrm{N}_{2}$ gas by bubbling for 30 min, each catalyst-coated WE was cleaned via potential sweeps from -0.8 to $0.2 \mathrm{~V}$ (vs. RE) in $0.1 \mathrm{M} \mathrm{KOH}(\mathrm{aq})$ or from 0.2 to $0.8 \mathrm{~V}$ (vs. RE) in $0.1 \mathrm{M} \mathrm{HClO}_{4}$ (aq), both for 60 cycles at $100 \mathrm{mV} \mathrm{s}^{-1}$. Following cleaning, background liner sweep voltammetry (LSV) data was collected using a rotation rate of 1600 rpm at a scan rate of $20 \mathrm{mV} \mathrm{s}^{-1}$. The oxygen LSV data was collected using the same protocol after the electrolyte was saturated with $\mathrm{O}_{2}$ by bubbling for $30 \mathrm{mins}$, which are presented after the deduction of background LSV and internal resistance $(i R)$ correction (determined by electrochemical impedance spectroscopy analysis at high frequencies). The electrochemical impedance spectroscopy (EIS) tests were conducted in $\mathrm{O}_{2}$ saturated electrolytes from $0.1 \mathrm{~Hz}$ to $1 \times 10^{5} \mathrm{~Hz}$ to at potential of $0.33 \mathrm{~V}$ with an amplitude of $5 \mathrm{mV}$ in $0.1 \mathrm{M} \mathrm{HClO}_{4}$ and $-0.13 \mathrm{~V}$ in $0.1 \mathrm{M} \mathrm{KOH}$. The electrons transfer number $\left(\mathrm{n}_{\mathrm{e}}\right)$ was calculated using the Koutecky-Levich $(\mathrm{K}-$ $\mathrm{L})^{2}$ equation with corrected LSV data using WE rotation rates of 400, 625, 900, 1225, and 1600 rpm. Catalyst stability was evaluated by accelerated degradation test (ADT), which performed 5000 potential sweep cycles (at a scanning rate of $200 \mathrm{mV} \mathrm{s}^{-1}$ ) in $\mathrm{O}_{2}$ saturated electrolyte with a potential range of 0.3 to $0.7 \mathrm{~V}(v s$. RE) in acid electrolyte or -0.4 to $0.1 \mathrm{~V}$ ( $v s$. RE) in alkaline electrolyte.

\section{PEMFC test}

The cathode gas diffusion electrodes (GDEs) were made by painting a catalyst ink (containing $32 \mathrm{mg}$ (i.e. $2 \mathrm{mg} \mathrm{cm}^{-2}$ ) of the ZnCoNC catalyst, $3 \mathrm{~mL}$ IPA and $90.5 \mu \mathrm{L}$ Nafion D1021 dispersion) onto the surface (one side) of a $4 \times 4 \mathrm{~cm}^{2}$ piece of 39BC GDL, followed by drying in the air. Commercial GDEs (Johnson Matthey, $0.4 \mathrm{mg}_{\mathrm{Pt}} \mathrm{cm}^{-2}$ ) were also painted with $90.5 \mu \mathrm{L}$ Nafion D1021 dispersion and used as the anodes. A cathode and anode GDEs were then sandwiched at both sides of a $6 \mathrm{~cm} \times 6 \mathrm{~cm}^{2}$ Nafion 212 membrane (catalyst layer facing the membrane) to form each membrane-electrode assembly (MEA), which were then hot pressed at $135^{\circ} \mathrm{C}$ under 4.9 $\mathrm{MPa}$ pressure for $2 \mathrm{~min}$.

Each fabricated MEA was tested at $80^{\circ} \mathrm{C}$ in a PEMFC test stand (PaxiTech-BioLogic FCT-50S, France). Polytetrafluoroethylene (PTFE) gaskets (254 $\mu \mathrm{m}$ thickness) were used at both the anode and cathode sides. Fully humidified $\mathrm{H}_{2}$ and air gases were supplied to the anode and cathode, respectively, with $\mathrm{H}_{2}$ /air stoichiometric ratios of 1.3/2.4, respectively (backpressure of 1.5 bar $_{\mathrm{g}}$ used with both gases). The MEA was hydrated by holding at a cell voltage of $0.5 \mathrm{~V}$ for $14 \mathrm{~h}$, after which the polarization curves were recorded at a scan rate of $1 \mathrm{mV} \mathrm{s}^{-1}$. Electrochemical impedance spectra (EIS) were recorded at a cell voltage of $0.5 \mathrm{~V}$ in the frequency range $10 \mathrm{KHz}$ to $0.1 \mathrm{~Hz}$ (the amplitude of the applied a.c. potential waveforms was $10 \mathrm{mV})$.

\section{AEMFC test}

A radiation-grafted LDPE-based benzyltrimethylammonium-type anion-exchange membrane (AEM, ion-exchange capacity IEC $=2.66 \mathrm{mmol} \mathrm{g}^{-1}, c a .55 \mu \mathrm{m}$ thick when fully hydrated $)^{3}$ and an ETFE-based radiation-grafted anion-exchange ionomer powder $\left(\mathrm{AEI}, \mathrm{IEC}=1.91 \mathrm{mmol} \mathrm{g}^{-}\right.$ 
$\left.{ }^{1}\right)^{4}$ were used to fabricate the alkaline MEAs. The geometric area of the electrodes was $5 \mathrm{~cm}^{2}$. The anode ink was prepared using water/IPA $(5 \mathrm{~mL} / 5 \mathrm{~mL})$ containing HISPEC $12100 \mathrm{PtRu} / \mathrm{C}$ catalyst and AEI powder (PtRu/C $=80 \mathrm{wt} \%$ and $\mathrm{AEI}=20 \mathrm{wt} \%$ of the solid mass, respectively), which was sprayed onto TGP-H-060 carbon paper to form the anode GDE: a Pt loading of 0.51 $\mathrm{mg} \mathrm{cm}^{-2}$ (i.e. total catalyst loading of $1.0 \mathrm{mg} \mathrm{cm}^{-2}$ ) was used. The $\mathrm{ZnCoNC}$ cathode was made by the same method, except the loading of the ZnCoNC catalyst used was $0.78 \mathrm{mg}_{\text {catalyst }} \mathrm{cm}^{-2}$. All AEI-containing catalyst inks were ultrasonicated for $30 \mathrm{~min}$ before spraying and the mixture was continuously stirred in a small vial with a magnetic stirrer at a rate of $500 \mathrm{rpm}$ when stored between ultra-sonification and being loaded into the spray gun.

MEAs were assembled in situ (no hot-pressing) by placing an anode, AEM, and a cathode (all ion-exchanged into the $\mathrm{OH}^{-}$forms [AEI and $\mathrm{AEM}$ ] using aqueous $1 \mathrm{M} \mathrm{KOH}$ ) inside the fuel cell fixture, which was then assembled with a torque of $5 \mathrm{~N} \mathrm{~m}^{-1}$. After the cell conditions were achieved $\left(70^{\circ} \mathrm{C}\right.$ cell temperature with gases supplied at $1 \mathrm{~L} \mathrm{~min}^{-1}$ with $68^{\circ} \mathrm{C}$ dew points and no gas back-pressurization), cell activation was conducted at $0.5 \mathrm{~V}$ cell discharge until a constant current discharge was obtained (this assists with uniform hydration and removal of any traces of excess $\mathrm{KOH}$ ). An initial beginning-of-life $\mathrm{H}_{2} / \mathrm{O}_{2}$ AEMFC test was then conducted with all data collected galvanostatically using a Scribner 850e fuel cell test station (which was also used to control supply the abovementioned gases). 


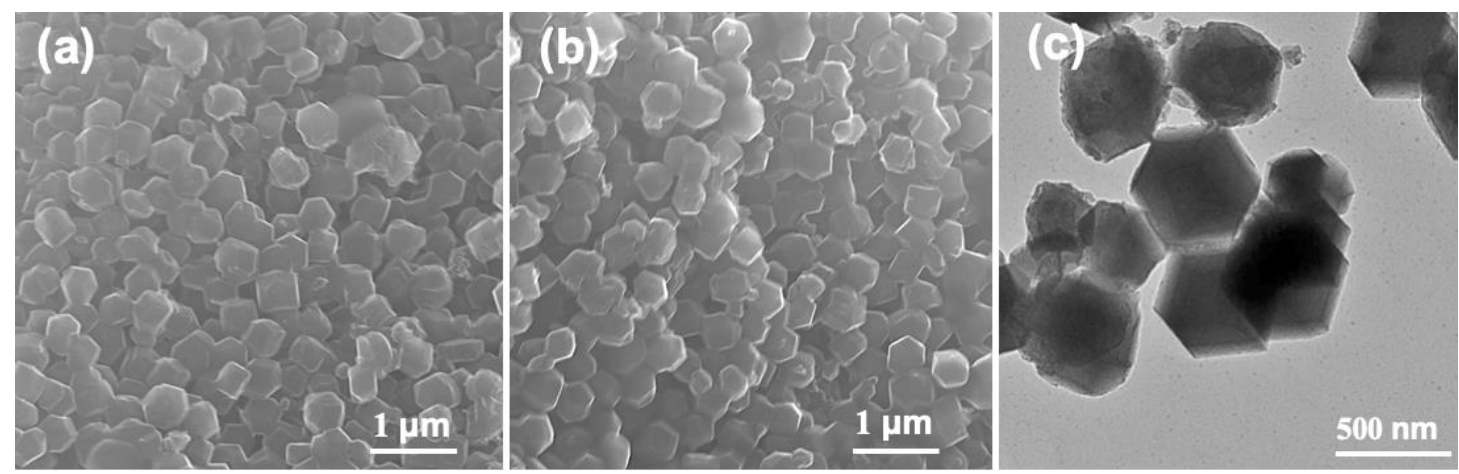

Figure S1. SEM images of (a) ZnCoNC and (b) ZnCoNC-IL20 catalysts. (c) TEM image of ZnCoNC-IL20.

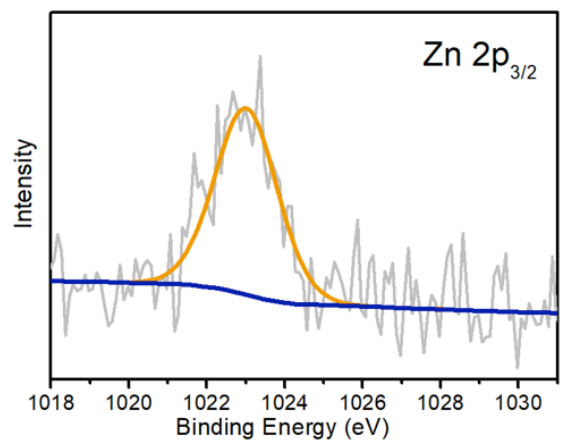

Figure S2. The high-resolution XPS region of $\mathrm{Zn} 2 \mathrm{p}_{2 / 3}$. 

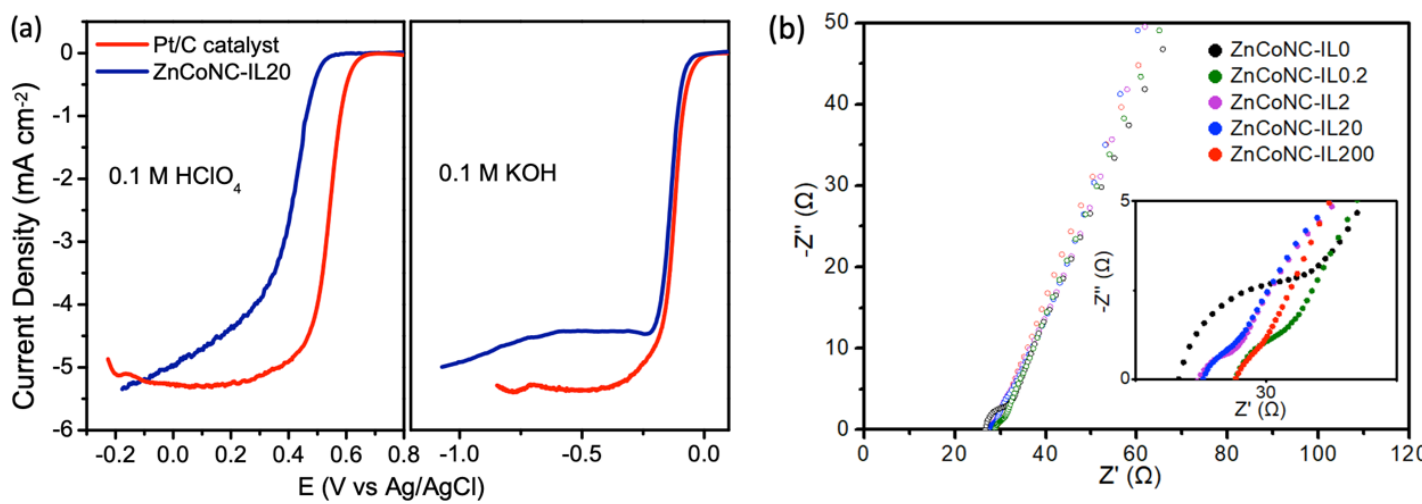

Figure S3. (a) ORR LSV curves of the ZnCoNC-IL20 and commercial Pt/C catalyst tested in $\mathrm{O}_{2}$ saturated $0.1 \mathrm{M} \mathrm{HClO}_{4}(\mathrm{aq})$ and $0.1 \mathrm{M} \mathrm{KOH}$ at a rotation rate of $1600 \mathrm{rpm}$ (scan rate $=20$ $\mathrm{mV} \mathrm{s}^{-1}$, Pt loading: $0.1 \mathrm{mg} \mathrm{cm}$ ). (b) Nyquist plots of the obtained catalysts tested in $\mathrm{O}_{2}$ saturated $0.1 \mathrm{M} \mathrm{HClO}_{4}(\mathrm{aq})$ (the inset is the enlarged view of the high-frequency area).
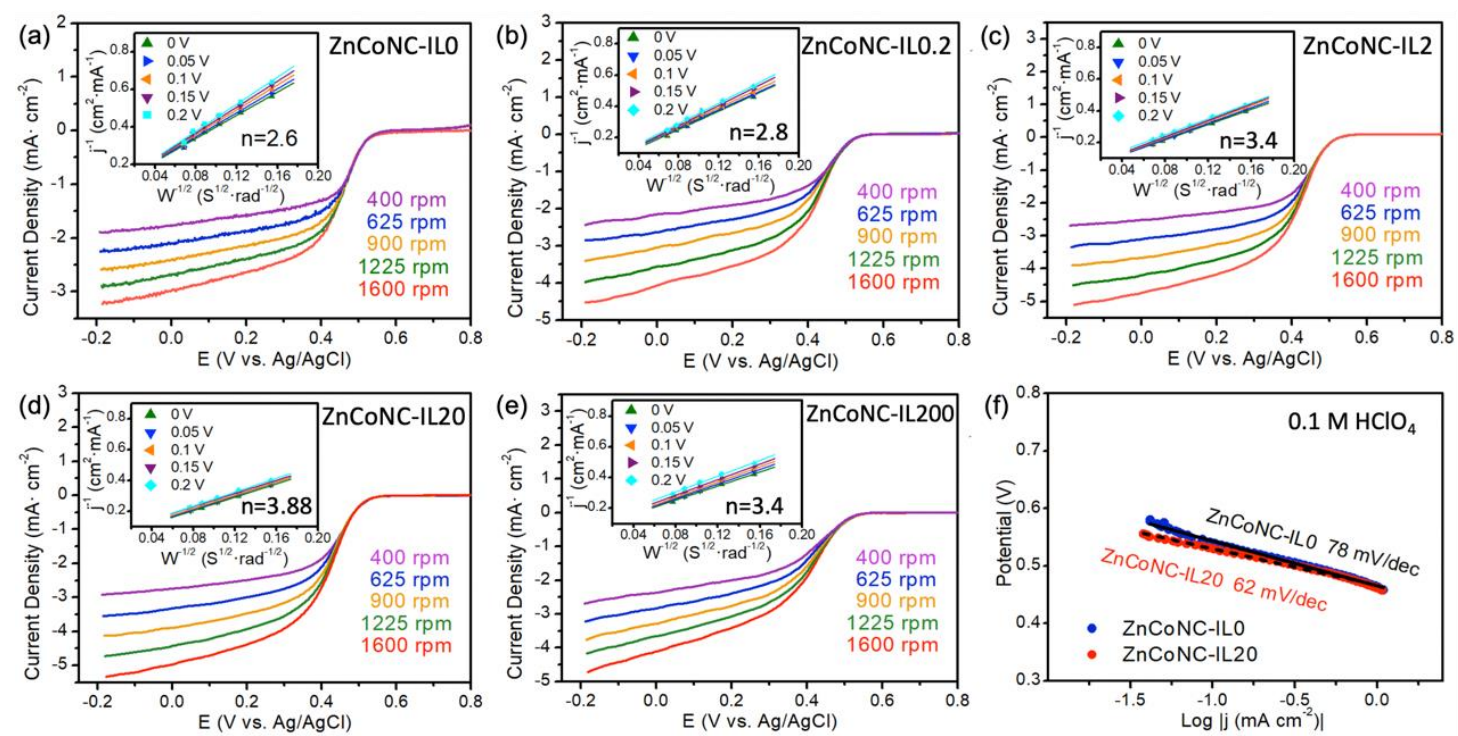

Figure S4. (a-e) ORR LSV curves for all IL-modified $\mathrm{ZnCoNC}$ catalysts tested in $\mathrm{O}_{2}$-saturated $0.1 \mathrm{M} \mathrm{HClO}_{4}(\mathrm{aq})$ at various rotation rates. (The insets are the corresponding $\mathrm{K}-\mathrm{L}$ plots at different potentials.) (f) Tafel plots of ZnCoNC-IL0 and ZnCoNC-IL20. 

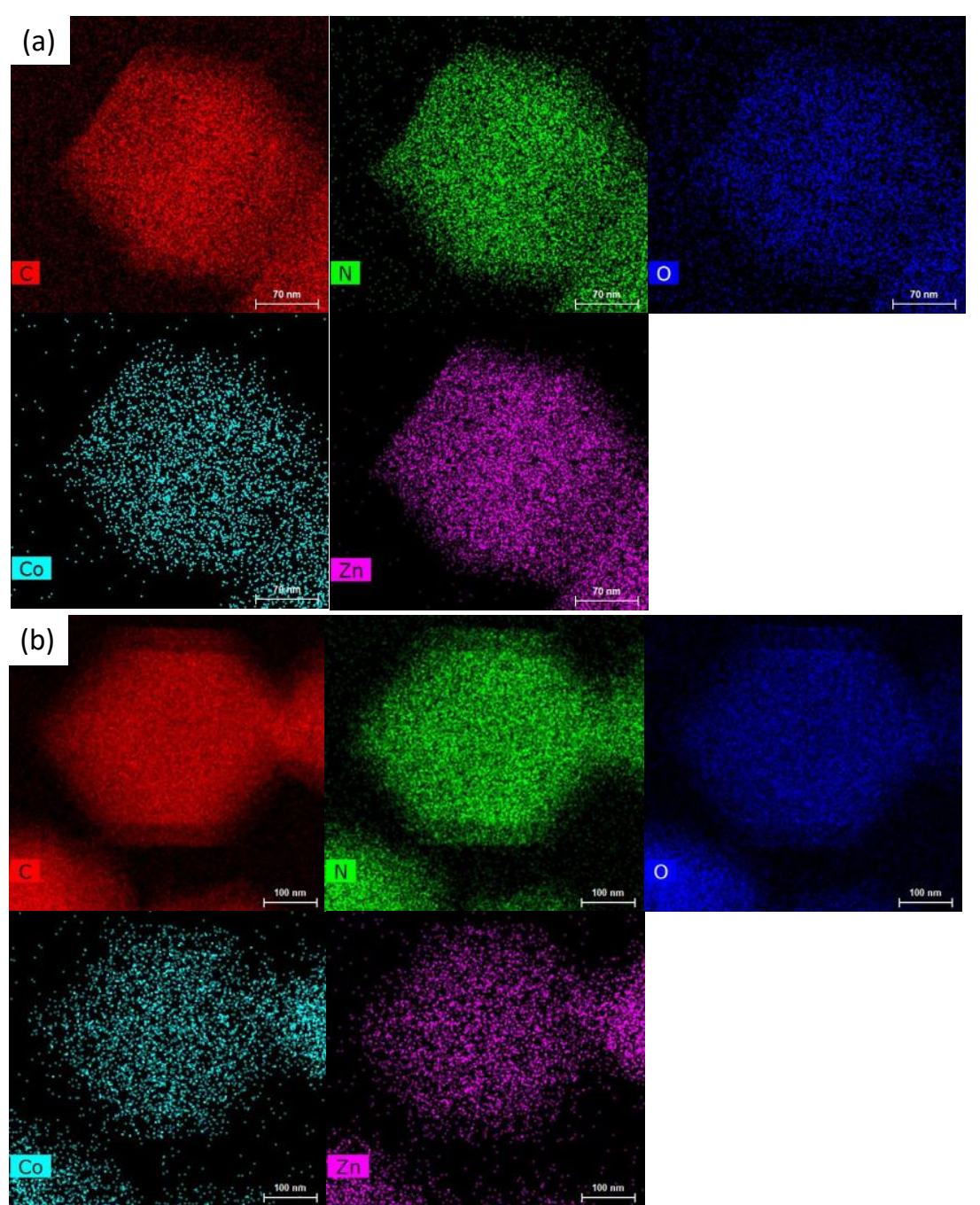

(c)

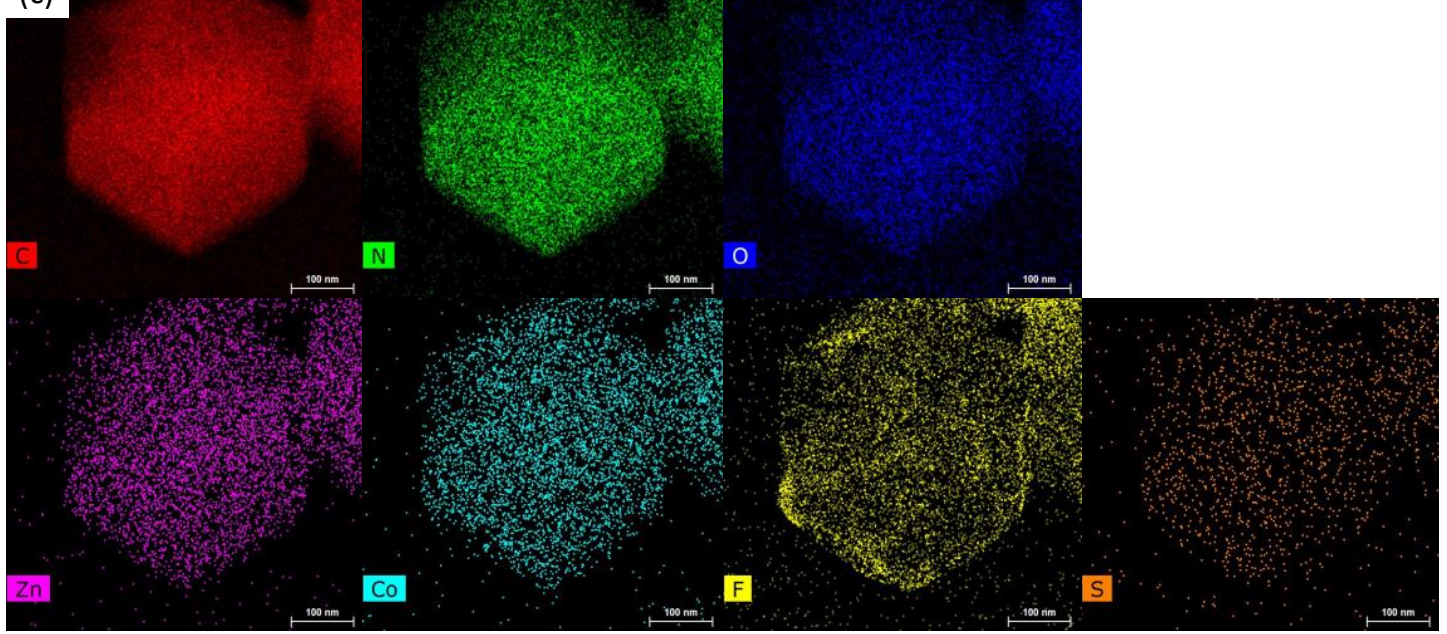

Figure S5. The elemental maps of (a) ZnCoNC-IL0 (scale bar: $70 \mathrm{~nm}$ ), (b) ZnCoNC-IL0 after the ADT (scale bar: $100 \mathrm{~nm}$ ) and (c) ZnCoNC-IL20 after the ADT (scale bar: $100 \mathrm{~nm}$ ) (the ADT was conducted in $\mathrm{O}_{2}$ saturated $0.1 \mathrm{M} \mathrm{HClO}_{4}$ ). 

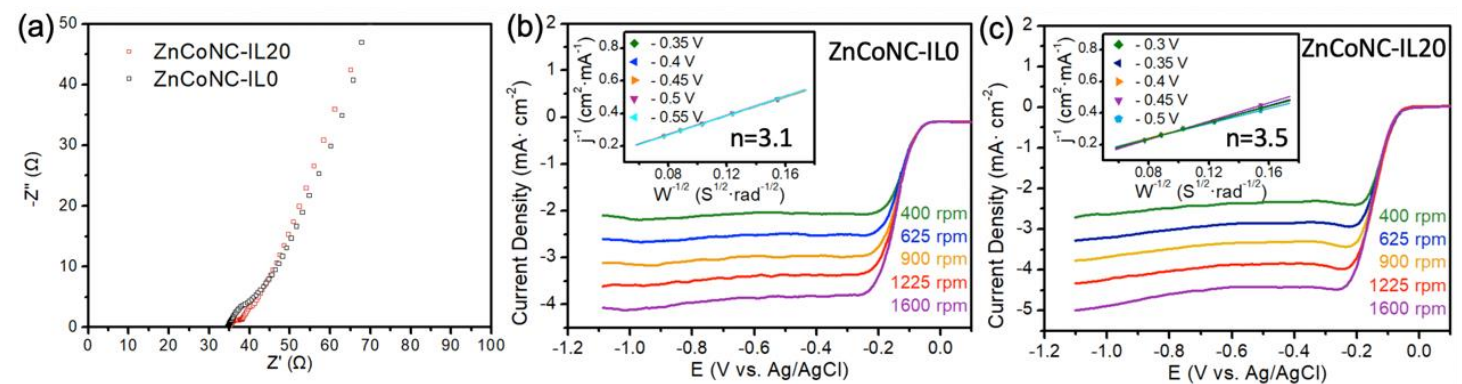

Figure S6. (a) The Nyquist plots for ZnCoNC-IL0 and ZnCoNC-IL20, and ORR polarization curves of (b) ZnCoNC-IL0 and (c) ZnCoNC-IL20 at various rotation rates in $\mathrm{O}_{2}$-saturated 0.1 $\mathrm{M} \mathrm{KOH}(\mathrm{aq})$. (The insets are the corresponding Koutecky-Levich plots at different potentials.)

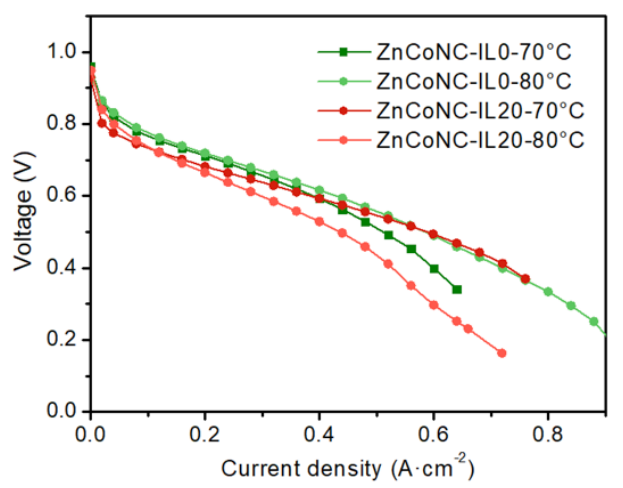

Figure S7. Comparison of $\mathrm{H}_{2} / \mathrm{O}_{2}$ AEMFC polarization plots at $70^{\circ} \mathrm{C}$ and $80^{\circ} \mathrm{C}$ (cathode $=0.78$ $\mathrm{mg}_{\mathrm{ZnCoNC}} \mathrm{cm}^{-2}$ and anode $=0.6 \mathrm{mg}_{\mathrm{PtRu}} \mathrm{cm}^{-2}$ ).

Table S1. The percentage of each element in ZnCoNC-IL0 and different amounts of IL modified ZnCoNC catalysts obtained from XPS analysis.

\begin{tabular}{|c|c|c|c|c|c|c|c|}
\hline Samples\Elements & $\mathrm{Co}$ & $\mathrm{N}$ & $\mathrm{C}$ & $\mathrm{O}$ & $\mathrm{F}$ & $\mathrm{S}$ & $\mathrm{Zn}$ \\
\hline ZnCoNC-IL0 & $4.66 \%$ & $10.52 \%$ & $45.11 \%$ & $14.68 \%$ & - & - & $25.03 \%$ \\
\hline ZnCoNC-IL0.2 & $2.41 \%$ & $10.93 \%$ & $47.89 \%$ & $16.93 \%$ & $0.64 \%$ & $0.40 \%$ & $20.80 \%$ \\
\hline ZnCoNC-IL2 & $2.27 \%$ & $11.46 \%$ & $48.07 \%$ & $17.17 \%$ & $2.23 \%$ & $0.61 \%$ & $18.19 \%$ \\
\hline ZnCoNC-IL20 & $2.03 \%$ & $10.95 \%$ & $48.19 \%$ & $17.43 \%$ & $2.61 \%$ & $0.89 \%$ & $17.90 \%$ \\
\hline ZnCoNC-IL200 & $0.28 \%$ & $9.37 \%$ & $21.24 \%$ & $19.98 \%$ & $38.56 \%$ & $8.63 \%$ & $1.94 \%$ \\
\hline
\end{tabular}


Table S2. Summary of the ORR activities of previously reported Co-based carbon catalysts.

\begin{tabular}{|c|c|c|c|c|c|}
\hline \multirow{2}{*}{ Catalysts } & \multirow{2}{*}{ Precursors } & \multicolumn{2}{|c|}{$\mathrm{E}_{1 / 2}(\mathrm{~V} v s . \mathrm{Ag} / \mathrm{AgCl})$} & \multirow{2}{*}{$\begin{array}{c}\text { The max power } \\
\text { density of fuel cell } \\
\left(\mathrm{W} \mathrm{cm}^{-2}\right)\end{array}$} & \multirow{2}{*}{ Ref. } \\
\hline & & Acid & Base & & \\
\hline $\mathrm{CoN}_{\mathrm{x}} / \mathrm{C}$ & $\begin{array}{c}\mathrm{Co}\left(\mathrm{NO}_{3}\right)_{2} \cdot 6 \mathrm{H}_{2} \mathrm{O} \\
\text { and, Imidazole, } \\
\text { carbon black } \\
\text { powders } \\
\end{array}$ & $\begin{array}{c}c a .0 .65 \\
(v s . \mathrm{RHE})\end{array}$ & -- & $\begin{array}{c}0.2 \\
\left(\mathrm{PEMFC}, \mathrm{H}_{2} / \mathrm{O}_{2}, 2\right. \\
\left.\mathrm{mg} / \mathrm{cm}^{2} \text { catalyst }\right)\end{array}$ & 5 \\
\hline $\mathrm{Co}-\mathrm{N}_{\mathrm{x}}$ & Co-ZIF & $\begin{array}{c}c a .0 .68 \\
\text { (vs. RHE) }\end{array}$ & -- & -- & 6 \\
\hline $\mathrm{CNCo}-20$ & Bimetal ZIF & -- & -0.15 & -- & 7 \\
\hline $\begin{array}{c}\text { Nano-P- } \\
\text { ZIF67 }\end{array}$ & ZIF 67 & -- & $\begin{array}{c}0.86(v s . \\
\text { RHE) }\end{array}$ & $\begin{array}{c}0.045 \\
\text { (alkaline DMFC, } \\
\text { Methanol } / \mathrm{O}_{2} \\
3 \mathrm{mg} / \mathrm{cm}^{2} \text { catalyst) }\end{array}$ & 8 \\
\hline $\begin{array}{c}\text { Co- } \\
\text { N/CNFs }\end{array}$ & $\begin{array}{c}\text { PAN, 4- } \\
\text { dimethylaminopyr } \\
\text { i-dine, cobalt } \\
\text { acetate }\end{array}$ & $\begin{array}{l}0.7 \text { (vs. } \\
\text { RHE) }\end{array}$ & $\begin{array}{c}0.82(v s . \\
\text { RHE) }\end{array}$ & $\begin{array}{c}0.016 \\
\text { (acid DMFC, } \\
\text { Methanol/air, } 4 \mathrm{mg} \\
\mathrm{cm}^{-2} \text { catalyst) }\end{array}$ & 9 \\
\hline $\begin{array}{c}\text { CoSAs/N- } \\
\mathrm{C}(800)\end{array}$ & Bimetal ZIF & -- & $\begin{array}{c}0.88(v s . \\
\text { RHE) }\end{array}$ & -- & 1 \\
\hline $\mathrm{Co} @ \mathrm{NC}$ & ZIF-67 & -- & $\begin{array}{c}c a .0 .79 \\
\text { (vs. RHE) }\end{array}$ & -- & 10 \\
\hline $\begin{array}{c}\text { 20Co-NC- } \\
1100\end{array}$ & Bimetal ZIF & $\begin{array}{c}0.8 \\
(v s . \mathrm{RHE})\end{array}$ & $\begin{array}{c}0.85 \\
(v s . \mathrm{RHE})\end{array}$ & $\begin{array}{c}0.28 \\
\left(\mathrm{PEMFC}, \mathrm{H}_{2} / \text { air, } 4\right. \\
\left.\mathrm{mg} / \mathrm{cm}^{2} \text { catalyst }\right) \\
\end{array}$ & 11 \\
\hline $\begin{array}{l}\text { This work } \\
\text { (ZnCoNC- } \\
\text { IL20) }\end{array}$ & ZIF-ZnCo & $\begin{array}{c}0.4 \\
(0.656 v s . \\
\text { RHE) }\end{array}$ & $\begin{array}{c}-0.14 \\
(0.825 v s . \\
\text { RHE })\end{array}$ & $\begin{array}{c}0.075 \\
\left(\mathrm{PEMFC}, \mathrm{H}_{2} / \text { air, } 2\right. \\
\left.\mathrm{mg} / \mathrm{cm}^{2} \text { catalyst }\right) \\
0.31 \\
\left(\mathrm{AEMFC}, \mathrm{H}_{2} / \mathrm{O}_{2}, 2\right. \\
\left.\mathrm{mg} / \mathrm{cm}^{2} \text { catalyst }\right)\end{array}$ & $\begin{array}{r}\text { This } \\
\text { work }\end{array}$ \\
\hline
\end{tabular}

Table S3. The element contents by EDS for ZnCoNC-IL0 (before the ADT), ZnCoNC-IL0 and ZnCoNC-IL20 after the ADT in $0.1 \mathrm{M} \mathrm{HClO}_{4}(\mathrm{aq})$.*

\begin{tabular}{|c|c|c|c|c|c|c|c|}
\hline $\begin{array}{c}\text { Sample/Elements } \\
\text { (wt \%) }\end{array}$ & Co & $\mathrm{N}$ & $\mathrm{C}$ & $\mathrm{O}$ & $\mathrm{F}$ & $\mathrm{S}$ & $\mathrm{Zn}$ \\
\hline ZnCoNC-IL0 & 0.12 & 12.15 & 78.04 & 4.54 & - & - & 5.16 \\
\hline $\begin{array}{c}\text { ZnCoNC-IL0 after } \\
\text { the ADT }\end{array}$ & 0.04 & 4.9 & 88.24 & 6.24 & - & - & 0.59 \\
\hline $\begin{array}{c}\text { ZnCoNC-IL20 after } \\
\text { the ADT }\end{array}$ & 0.07 & 5.57 & 87.57 & 4.95 & 0.63 & 0.28 & 0.93 \\
\hline
\end{tabular}

(*All samples were prepared on the carbon film support and this adds up to the high content of carbon percentage.) 


\section{References}

(1) Yin, P.; Yao, T.; Wu, Y.; Zheng, L.; Lin, Y.; Liu, W.; Ju, H.; Zhu, J.; Hong, X.; Deng, Z. Single Cobalt Atoms with Precise N-coordination as Superior Oxygen Reduction Reaction Catalysts. Angew. Chem., Int. Ed. 2016, 55 (36), 10800-10805.

(2) Kothandaraman, R.; Nallathambi, V.; Artyushkova, K.; Barton, S. C. Non-Precious Oxygen Reduction Catalysts Prepared by High-Pressure Pyrolysis for LowTemperature Fuel Cells. Appl. Catal. B Environ. 2009, 92 (1-2), 209-216.

(3) Wang, L.; Brink, J. J.; Liu, Y.; Herring, A. M.; Ponce-González, J.; Whelligan, D. K.; Varcoe, J. R. Non-Fluorinated Pre-Irradiation-Grafted (Peroxidated) LDPE-Based Anion-Exchange Membranes with High Performance and Stability. Energy Environ. Sci. 2017, 10 (10), 2154-2167.

(4) Gonçalves Biancolli, A. L.; Herranz, D.; Wang, L.; Stehlíková, G.; Bance-Soualhi, R.; Ponce-González, J.; Ocón, P.; Ticianelli, E. A.; Whelligan, D. K.; Varcoe, J. R.; et al. ETFE-Based Anion-Exchange Membrane Ionomer Powders for Alkaline Membrane Fuel Cells: A First Performance Comparison of Head-Group Chemistry. J. Mater. Chem. A 2018, 6 (47), 24330-24341.

(5) Ma, Y.; Zhang, H.; Zhong, H.; Xu, T.; Jin, H.; Tang, Y.; Xu, Z. Cobalt Based NonPrecious Electrocatalysts for Oxygen Reduction Reaction in Proton Exchange Membrane Fuel Cells. In Electrochimica Acta; 2010; Vol. 55, pp 7945-7950.

(6) Ma, S.; Goenaga, G. A.; Call, A. V; Liu, D. J. Cobalt Imidazolate Framework as Precursor for Oxygen Reduction Reaction Electrocatalysts. Chem. - A Eur. J. 2011, 17 (7), 2063-2067.

(7) Chen, Y. Z.; Wang, C.; Wu, Z. Y.; Xiong, Y.; Xu, Q.; Yu, S. H.; Jiang, H. L. From Bimetallic Metal-Organic Framework to Porous Carbon: High Surface Area and Multicomponent Active Dopants for Excellent Electrocatalysis. Adv. Mater. 2015, 27 (34), 5010-5016.

(8) Ai, K.; Li, Z.; Cui, X. Scalable Preparation of Sized-Controlled Co-N-C Electrocatalyst for Efficient Oxygen Reduction Reaction. J. Power Sources 2017, 368, 46-56.

(9) Cheng, Q.; Yang, L.; Zou, L.; Zou, Z.; Chen, C.; Hu, Z.; Yang, H. Single Cobalt Atom and N Codoped Carbon Nanofibers as Highly Durable Electrocatalyst for Oxygen Reduction Reaction. ACS Catal. 2017, 7 (10), 6864-6871.

(10) Li, X.; Jiang, Q.; Dou, S.; Deng, L.; Huo, J.; Wang, S. ZIF-67-Derived Co-NC@CoPNC Nanopolyhedra as an Efficient Bifunctional Oxygen Electrocatalyst. J. Mater. Chem. A 2016, 4 (41), 15836-15840.

(11) Wang, X. X.; Cullen, D. A.; Pan, Y. T.; Hwang, S.; Wang, M.; Feng, Z.; Wang, J.; Engelhard, M. H.; Zhang, H.; He, Y.; et al. Nitrogen-Coordinated Single Cobalt Atom Catalysts for Oxygen Reduction in Proton Exchange Membrane Fuel Cells. Adv. Mater. 2018, 30 (11), 1-11. 